\title{
A Short History of the Use of Lime as a Building Material - Beyond Europe and North America.
}

By Dorn Carran ${ }^{1}$, John Hughes ${ }^{1}$, Alick Leslie ${ }^{2}$ and Craig Kennedy ${ }^{3}$

${ }^{1}$ School of Science and Engineering UWS Paisley

Paisley

PA1 2BE

Tel: 01418483502

E-Mail: Silversundance@hotmail.com

${ }^{2}$ British Geological Survey

Murchison House

West Mains Road

Edinburgh

EH9 3LA

${ }^{3}$ Historic Scotland

Technical conservation Group

7 South Gyle Crescent

Edinburgh

EH12 9EB 


\title{
A Short History of the Use of Lime as a Building Material Beyond Europe and North America
}

\begin{abstract}
The use of lime in building construction began at least 10,000 years ago, with debated evidence of earlier uses. The focus of academic research on historical and archaeological use of lime has, to date, focussed on Europe and the Near East. This work is an attempt to provide a summary of the history of lime as a building material in China, India, Africa, Central and South America, based on available literature resources. Patterns of functional evolution suggest beginnings in small scale domestic surface coating evolving later to more widespread use linked to societal development in the regions considered. Commonalities exist in material characteristics and usage between different societies, linked to technological progress rather than absolute chronology.
\end{abstract}

\author{
Keywords: History, Architectural History, Lime, Lime Mortar, Building \\ Materials, China, India, Africa, South America, Mesoamerica
}

\section{Introduction}

Lime has been used for nigh over two thousand years within mortar, internal plaster, external render, foundations, flooring, infilling of walls, casing of water conduits, jointing compounds and decorative applications (Elsen 2006). Many publications detail the history of lime as a building material either as a result of general work in the field or as part of a more specific study. An abundance of material exists to document 
the substances use throughout the West, however many other parts of the world tend to be neglected. Several resources document the use of lime in these regions; however none tend to combine this knowledge. This work is an attempt to provide this through a short but detailed summary.

Every small locality of the world has developed its own style and practice in regards to building techniques. This article does not seek to describe them all in great detail but rather to draw attention to four key regions - China, India, Africa and Mesoamerica/South America - in order to compare and contrast in general terms the evolution of lime as a building material in a global context. Where no sources relating to the direct use of lime mortar are available, then a description of the architecture of the region has been included as this may allow a determination as to whether lime mortar may or may not have been used.

Other than mud, earth and clay, lime is one of the oldest binding materials to be used in construction. Prior to the development of concrete, lime mortar was used to construct some of the world's most renowned buildings; now it is primarily used for their repair.

For those with little knowledge of lime mortar, it is made in a three stage process. This process is as follows;
1) Calcination
$\mathrm{CaCO}_{3}+$ heat $\rightarrow \mathrm{CaO}+\mathrm{CO}_{2}$
2) Hydration
$\mathrm{CaO}+\mathrm{H}_{2} \mathrm{O} \rightarrow \mathrm{Ca}(\mathrm{OH})_{2}+$ Heat
3) Carbonation

$$
\mathrm{Ca}(\mathrm{OH})_{2}+\mathrm{CO}_{2} \rightarrow \mathrm{CaCO}_{3}+\mathrm{H}_{2} \mathrm{O}
$$

(Boynton 1980) 
This three stage process is known as the Lime Cycle. Stage 1 is achieved by burning limestone to a temperature of $\mathrm{c} .900^{\circ} \mathrm{C}$ to produce a light coloured and lightweight material known as quicklime (this is the $\mathrm{CaO}$ ). Stage 2 is performed by adding water to the quicklime in a process termed slaking. Once the quicklime is slaked it becomes a calcium hydrate which can then be mixed with an aggregate to form a mortar. Once this mortar has been applied to a building, stage 3 occurs, resulting in the return of the calcium hydrate to calcium carbonate (Boynton 1980).

The benefits of lime were most likely the result of an accidental discovery. It is well known that many indigenous tribes, both from the past and the present, used to cook using hot stones (Grattan 2008). It is quite conceivable that such people cooking with limestone would have noticed the change it underwent due to heating, and later its reaction with water and the subsequent hardening to a light coloured substance akin to stone.

Within mortars the oldest binder was known to be mud (soil or silt mixed with water), closely followed by clay (deposits of phyllosilicate rich earth that displays plastic properties), as verified by the finds at Catal Hüyük, Turkey, dating from 6000BC (Elsen 2006). By the $6^{\text {th }}$ millennium BC, as agriculture began to spread westward into Europe and the first use of brick appeared at Catal Hüyük, lime began to be implemented as a binder (Elsen 2006; Roberts 1994; Robertson et al. 1976). Evidence for the early use of lime tends to be found in the form of plaster which was used to coat walls and floors. Examples of these sites include Ain Ghazal, Yiftahel (Western Galilee, Israel) and Abu Hureyra (Upper Euphrates, Syria) which date to the Pre Pottery Neolithic B Period (7500-6000 BC, Mazar 1992). It is believed that this early 
use of plaster led to the development of proto-pottery, which was made from fired lime and grey ash (Mazar 1992).

The Levant is an important archaeological area because of its abundance of prehistoric remains. As such, it has been highly studied by many archaeologists; several of these, such as Goren and Goring-Morris (2008), have skills in petrography and have studied early pyrotechnology, including the production of lime. As a result of their work at the site of Kfar Hattoresh, near Nazareth, Goren and Goring-Morris (2008) have concluded that lime plaster in the Levant was used extensively and was considered as both a utilitarian and a symbolic product; as evidenced by its use as a modelling agent on skulls found at the site and its' use as a sealing agent in burials throughout the Levant. The petrographic study of such prehistoric lime plaster shows that lime lumps and overburnt or unreacted quicklime were common in samples; such lumps were deemed to be a reflection of the crude production techniques in use at the time (Karkanas 2007).

The date of $6000 \mathrm{BC}$ for the earliest use of lime is arguable, as can be seen in the work of Kingary et al. (1988). Kingary et al. make reference to the Hayonim Cave in Israel which dated to $10,400-10,000 \mathrm{BC}$. Within the cave is a room $2.5 \mathrm{~m}$ in diameter which contained a $20 \mathrm{~cm}$ thick white layer of porous material (Kingary et al. 1988). The cave itself had an opening resembling a chimney and contained signs of human occupation in most of its five rooms, including signs of cooking large and small mammals. The excavator has stated that this white residue represents the use of a lime kiln. Kingary et al. (1988) analysed the layer, the microstructure of which was seen to contain limestone fragments surrounded by small rounded bodies of pure calcium 
carbonate, that they interpret to represent the carbonated products of lime calcination, identified as such by analogy with contemporary lime samples. However, what is not mentioned is that the caves themselves are limestone (Mercier et al. 2007), so the same result could be gained from the effect on the natural stone through hearth fires The recognition of calcium carbonate layers as lime processing sites is problematic, as is seen with the Mayan sites discussed later.

Another early date for the appearance of lime mortar is given in details of archaeological finds found upon the French Polynesian island of Kuni in the 1960's (Joseph 2006). On this island were 400 plus tumuli (earthen mounds) that were excavated and were found to each contain a cylinder made of hard lime mortar ranging from 4 inches wide to $2 \mathrm{ft}$ wide, with the largest being $7 \mathrm{ft}$ in length. The mortar, which was seen to contain shells, iron fragments and gravel, was radio carbon dated and was found to originate from 11000BC (Joseph 2006). As with Kingary's evidence, caution must be taken when using this data as the book from which the reference was taken uses the archaeological evidence from Kuni in an attempt to justify the existence of the Atlantis-like mythical land of Lemuria.

Lime mortar was not widely used until it was adopted by the Greeks and later the Romans around the 1st millennium BC (Blezard 1998). Prior to this it was more commonly used as a plaster, as can be seen at the Cheops pyramid, and at the site of Timna, Egypt in 1400-1200 BC (Gourdin and Kingary 1975).

One of the most important early references to lime mortar comes from Vitruvius's De Architectura, written c.25 BC. These important works, written as a guide for building 
projects, refer to Opus Incertum, lime mortared walling, the development of which Vitruvius attributes to the Greeks (Winfield 2006). Although the Romans did not fully understand the properties/technology of hydraulic lime, they did recognise the need for such a mortar when building water related structures; they commonly addressed this problem by including crushed ceramics, crushed brick or volcanic tuff as a pozzolan within the mortar mix. This is evidenced in the petrographic study of samples taken from the Roman city of Sagalassos in Turkey, by Degryse et al. (2002); within these mortars the common pozzolanic additives included crushed ceramics and volcanic tuff.

The Greeks renewed their interest in Lime mortar after it was refined by the Roman military engineers. A development that assisted the mass and expeditious reconstruction of the Byzantine military defences after the Slav and Persian invasions of the $5^{\text {th }}$ and $6^{\text {th }}$ Centuries AD as well as after the Arab invasions of the $7^{\text {th }}$ to $9^{\text {th }}$ Centuries AD (Winfield 2006). Such walls used the Opus Incertum design which was externally coated in lime plaster to protect against water penetration. Examples of such work are numerous throughout Greece, the Balkans and Asia Minor dating from the $6^{\text {th }}$ to the $15^{\text {th }}$ Century (Winfield 2006). These later mortars often used crushed brick as pozzolans and were also characterised by facings which were often up to 70mm in thickness (Baronio et al. 1996).

Between the fall of the Roman Empire and the medieval period, history is sketchy in terms of building development and architectural advancement. Little is known about the use of lime mortar during this time, but it is thought that the traditions continued to have been implemented but on a smaller scale than before. Within England, the 
arrival of the Normans in 1066 saw a dramatic rise in the use of stone structures and therefore the use of lime as a binder. Such structures included the numerous castles and churches built by William the Conqueror in order to obtain both military and political control over the English. During the period 1066 - 1087, 86 stone castles were constructed throughout England, quite a feat considering castles generally averaged 7-12 years construction time (Alchin 2005).

In the early industrial era people began to experiment with mortars in an attempt to improve on the current design. It was in 1756, prior to the construction of the Eddystone Lighthouse, that John Smeaton first recognised that the hydraulic properties of the lime could derive from clay impurities within the limestone; this he referred to as Water Lime (Blezard 1998). Later, Louis Vicat (1786-1861), coined the term Hydraulic Lime and devised the categorisation of such limes based upon their hydraulic nature. These terms are: Fat Lime, Lean Lime, Moderately Hydraulic Lime, Hydraulic Lime and Eminently Hydraulic Lime (Vicat 1837). The next major development came in 1796, when the clergyman James Parker developed Roman Cement, a form of cement which used a naturally hydraulic binder; this mixture remained popular until the late 1800's (Hughes and Válek 2003).

On $21^{\text {st }}$ October, 1824 a patent was lodged for a mixture termed Portland cement by a Joseph Aspdin. This mixture involved grinding crushed and calcined limestone into fine wet slurry, to which clay was added before undergoing a second phase of calcination (Sickels 1987). Whilst this was not similar to today's cement, it paved the way for many similar developments. Nineteen years later, I.C. Johnson, using a vitrified binder, produced the form of Portland cement which is closest to today's 
modern mixture (Sickels 1987). As a result of these new developments, the turn of the century saw the gradual phasing out of lime mortar in favour of Portland cement for many applications.

\section{The Use of Lime in China}

Very few western resources detail the use of lime in China and Asia. This, no doubt, is due to the language barrier; therefore much of the evidence for the use of mortar in Asia has been pieced together from several short articles written in English by Chinese scholars or from general studies of China's architectural history.

China is one of the oldest civilisations in the world, with a history that dates back 10000 years (Pheng 2007). The country became an Empire in $221-206 \mathrm{BC}$ at the beginning of the Qin dynasty and remained so until the end of the Qing dynasty in 1911 (Pheng 2001).

\section{Early Construction Techniques}

The earliest form of housing within China took the form of nests and caves. Nests were found in lowland regions whilst the caves were common in the upland areas (Pheng 2001). Nests were the common dwelling of the Hemudu Culture which developed along the Changjiang river 6000 - 7000 years ago (Pheng 2007). Nest dwellings gradually fell into disuse and cave dwellings became more common. Caves were initially bag shaped with makeshift coverings that could be removed in fine weather; these were then succeeded by semi-underground caves with a permanent 
roof structure, before people eventually moved above ground (Golany 1992). The above ground structures tended to consist of wood framed walls plastered with mud, examples of which could be found near Bianpo, in Xian (Pheng 2001).

A key construction method which led to the development of more permanent and substantial settlements is that of ramming earth. This was developed in the Shang Dynasty $(1700-1027$ BC) and involved the practice of compacting earth through the use of weight bearing columns. Earth ramming led to the construction of weight bearing walls and mounds for building larger structures such as the palace at Erlitou, in Henan (Pheng 2001). Vast city structures began to be developed during the rule of the Shang dynasty $(1700-1027 \mathrm{BC})$ and the Zhou Clan $(1027-221 \mathrm{BC})$ as a result of the earlier introduction of a complex slave labour system during the period of the Xia dynasty (c.2000-1500 BC) (Pheng 2001).

\section{The First Use of Lime and its Implementation throughout Time}

In the mid to late West Zhou period (1046 - $771 \mathrm{BC})$ lime was often used for the reinforcement of pillar bases, in groundwork and for various roofing applications (Yang et al. 2009). The Shang Dynasty (1700 - 1027 BC), saw the construction of many palaces, as well as the introduction of innovative developments such as the roofing tile. The roofs of peasant houses consisted of reeds laid over rafters which were covered with straw mixed with mud. Over the mud covering, a layer of sand, lime and loess (windblown, loosely consolidated fine sand to clay, often calcareous; large deposits are found in the USA, China, Hungary and Belgium) was applied (Pheng 2001). 
Tiles were restricted to the roof ridges and eaves to prevent leakage by rainwater (Pheng 2001). During the Zhou and Shang dynasties, floors were either made of a lime facing, or consisted of lime, sand and loess that was occasionally baked (Golany 1992). At the palace site of Xianyang, in the Shaanxi Province (built in 350BC), the ground was found to be constructed from pig's blood, lime and stone; the pig's blood gave the floor a maroon colour (Yang et al. 2009). It was also known that during this period wall facings of simple buildings were made of mud or lime mixed with straw, or a mixture of sand, lime and loess (Pheng 2001).

In the East Zhou period (770 - $221 \mathrm{BC})$, lime was used often in tomb construction; evidence of which can be found in the text - Zuo Zhuan - which states that when Duke Wen of Song died in the $2^{\text {nd }}$ year of Duke Cheng of Lu (635 BC) that clam lime (lime made from clam shells), was used to construct his elaborate tomb (Yang et al. 2009).

During the Han Dynasty (206 BC - 8 AD) many tombs implemented the use of lime in their construction and adornment, figure 1 shows how well constructed these early tombs were. It was during this period that the product known as Tabia was invented; this was initially a mortar like material composed of lime, sand and loess, which was widely used throughout the Empire, especially during the Eastern Tsin Dynasty (317 420 AD) (Yang et al. 2009). Brick and Tile used in the construction of buildings were made within kilns built at the construction sites; as a result it is likely that mortar was also created on site (Pheng 2007). By the Eastern Han period (25-220 AD) the 
production of lime must have been well established because its' use became common in the earliest forms of paper, developed in China in 105AD (UPSA 2007).

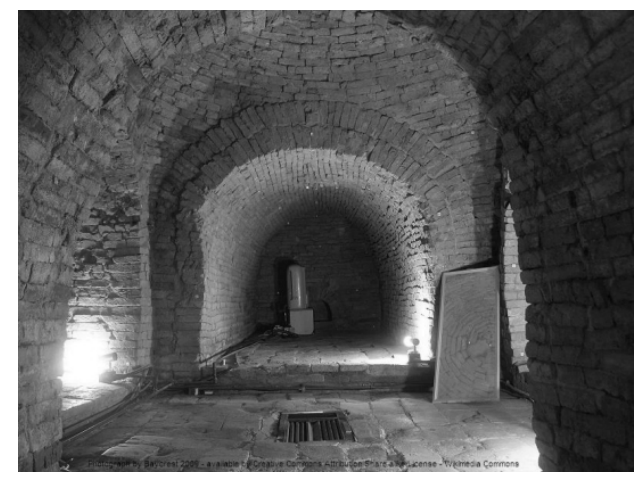

Figure .1. The interior of the tomb of Lei Cheng. A Han period tomb from the Kowloon Peninsula, Hong Kong (Baycrest 2009 - made available under the Creative Commons Attribution Share Alike License - Wikimedia Commons).

Primary Sources

Primary sources detailing Chinese construction techniques are rare because construction skills were not rated as highly as the arts in China. Two key sources exist; these being the Yingzao Fashi (Treatise on Architectural Methods), and the Gongbu Gongcheng Zuofa Zeli (Engineering Manual for the Board of Works). The Yingzao Fashi was published by the Public Office of Building within the Ministry of Public Works, in the Song Dynasty (960 - 1279 AD), and the Gongbu Gongcheng Zuofa Zeli was published by the Public Ministry of Public Works during the Quing Dynasty (1644 - 1911 AD) (Pheng 2007). The Yingzao Fashi includes a chapter which lists the ingredients used in mortars and plasters as well as references to stone and brick work. Further details of this document are unavailable as no full English translation of this work exists. Later works such as the Tian Gong Kai Wu, written in the Ming Dynasty $(1368-1644)$ are more common. The Tian Gong Kai Wu records the composition of mortars as being a mixture of sticky rice soup, Actinidia chinensis 
cane juice, $1 / 3^{\text {rd }}$ lime and $2 / 3^{\text {rd }}$ s loess (wind blown silt cemented with calcium carbonate) and river sand. This is believed to be the full composition of the Tabia mixture previously mentioned (Yang et al. 2009).

\section{Lime Mortar Compositions}

Organic materials were often added to lime mortar; other than sticky rice soup, there is evidence for the addition of vegetable and fruit juices such as star fruit cane, the leaves of the Marshpepper Knotweed plant and the Bletilla striata orchid, as well as egg whites and animal blood. It is also known that putties made from tung oil, fish oil and lime were often used within both building and ship construction (Yang et al. 2009). Many of the lime mortars used in China can be considered organic / inorganic hybrids; researchers at the Chonggong and Zhejiang Universities in China have studied these hybrid mixes and have found that the inclusion of additives such as sticky rice can increase the compressive strength of a mortar by 30 times and the surface toughness by 2.5 times (Yang et al. 2009). It is found that polysaccharides like sticky rice can affect the size, shape and structure of carbonate crystals, making them more compact and therefore stronger and can improve the flexibility of the mortar by working in unison with the calcite within the mixture (Yang et al. 2009; Zeng et al. 2008).

This has been seen in the ancient towers of the Tang and Song Dynasties in Quan County that survived a 7.5 grade earthquake in 1604 and the tomb of $\mathrm{Xu} \mathrm{Pu}$ and his wife (Ming Dynasty) that proved difficult even for a bulldozer to damage (Yang et al. 2009). 


\section{The Use of Lime in India and the Surrounding Regions}

\section{Early Construction Techniques}

The early inhabitants of India and Pakistan were the Indus Valley Civilization (which emerged around 5500 BC), can be considered alongside China, Egypt and Mesopotamia as another of the world's oldest civilisations (Lal 1997). The Indian Bronze age lasted from 3000 - $1200 \mathrm{BC}$, during which time the technologically advanced Harappan period (3300 - 1300 BC) emerged. It is named after the first city of the period to be excavated, Harappa in Pakistan (Lal 1997). The Harappan people tended to inhabit large urban cities from $2600 \mathrm{BC}$; cities such as Harappa were planned by the municipal governments and consisted of brick built buildings which included a very sophisticated sanitation system as well as substantial brick built city walls (Lal 1997). The only mortars in use at this time were made from mud or were Vajralepa mortar. Vajralepa mortar is a bituminous substance made from wood-tar which was used as a water proof coating for walls and structures within bathhouses (Sengupta 2005).

\section{The First Use of Lime and its Implementation throughout Time}

Lime was used on occasion in the early period, as evidenced from the deposits of lime plaster lining the ovens and cylindrical pits found within the houses of the site of Kalibangan, Rajasthan (IGNCA 2009). These structures date to the proto-Harappan period, 3500 - 2500 BC (IGNCA 2009); however the widespread use of lime in 
structures is not common until much later as is seen within the structures at the Buddhist settlement of Nagarjuna-Konda, the capital of the Ikshvaku dynasty (225325 AD) (Ghosh 1990). Lime plaster was more commonly used amongst the early civilizations of India; it contained a lot of sand and clay which is thought to be indicative of the use of kankar (masses or layers of calcium carbonate found within alluvium and clay). Lime plasters from the city of Kausambi (35 - 350 AD) in Uttar Pradesh, were found to contain a variety of ratios of sand: lime; these ranged from 1:1 - to 4:3 (Ghosh 1990). These plasters were not very pure as they contained gypsum, clay and phosphate as well as the sand and lime (Prakash and Rawat 1961).

Much of the literature for the architecture of India and Asia relates to the religious buildings of the various faiths. Initially India's religion was dominated by Buddhism, but as invaders entered the region, they brought with them the Islamic faith (Smith 1999). As a result mosques began to appear throughout the country - initially these were in the form of bamboo and thatch huts, but gradually brick buildings became more common, as did the use of a dome and a square floor plan (Kuban 1974). The mosques within the region of Bengal were primarily built within the Restored Ilyas Shahi (1433 - 1486) and the Husayn Shahi (1493 - 1538) dynasties and represented a fusion of Bengali and migrant technologies (Hasan 2007).

Brick was the dominant construction material due to the abundance of clay in Bengal. The two outer sides of brick mosques were of dressed masonry with lime mortar; the core of the walls were constructed from more casual brickwork lain in a bed of mud mortar (Hasan 2007). The walls of the Sultanate mosques were unplastered as brickwork was made decorative or was adorned with terracotta tiles. Lime was used 
as a mortar and a plaster on the parapets, roof and domes of mosques in order to provide a degree of water resistance. Such lime was found to have a high clay content, and contained sand and powdered brick as an aggregate (Hasan 2007).

In India, many monuments built by the Qutb Shahis $(1518-1687)$ in and around the city of Hyderabad, often used lime mortar in their construction as can be seen at the tomb of Muhammad Qutb Shah (figure 2)(Seshan 2002). The Qutb Shahis used the earlier styles of the Bahamani's and developed them into their own, the prime example of which is considered to be the Charminar (the mosque of the four minarets) (figure 3). The Charminar was built in 1591 - 93 by Quali Qutub Shah, the fifth ruler of the Qutub Shahi, and was constructed from granite and lime mortar (Seshan 2002). The lime was locally sourced and contained shell, jaggery (an unrefined sugar) and egg whites which were used to enhance the properties of the mortars and plasters (Singh 1993).

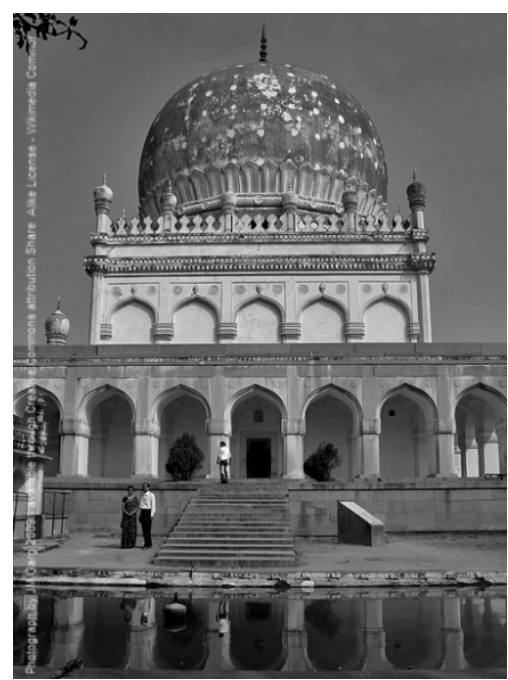

Fig.ure .2. The tomb of Muhammad Qutb Shah in Hyderabad, India (JM Garg 2009 - made available under the Creative Commons Attribution Share Alike License - Wikimedia Commons). 


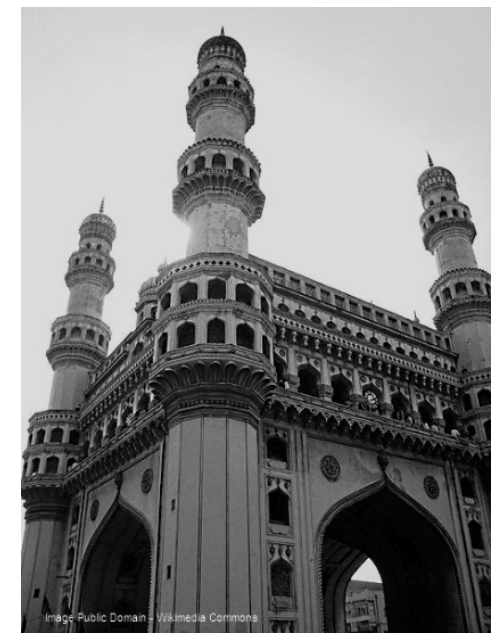

Figure ..3. The Charminar (Image - Public Domain, Wikimedia Commons)

It is rumoured that the chief architect responsible for the construction of the Charminar disappeared shortly into the construction. Upon his re-appearance a few years later, he gave the excuse that he had absconded only for the required period for the lime to mature (Ali 2001). The point made in regards to the maturation of the lime is an interesting one. Lime mortar can be made by slaking the lime and then leaving it or storing it as putty, instead of adding the aggregate immediately or turning the lime into a dry hydrate (dry hydrated lime powder). The lime putty develops a skin of carbonate which allows the material to be stored for a long period of time before use. The benefits of storing putty have been argued, but it is considered that the process of maturation increases the plasticity, workability and water retention of the final product. It is known that the Romans would often store lime putty for a matter of years, passing the supplies from father to son. So this supposition by the architect could be based upon an actual practice in India which is not referenced in other literary sources.

The use of lime in later India was quite common, and its use would have partially been influenced by the Western colonialists. The Krishan Mandir temple (built in 
1830) in the village of Krishankot in the Punjab used not only lime mortar in its construction but also lime plaster and limewash (Rai and Pandit 2000). Initially the temple was built of burnt bricks placed in a bed of lime mortar and covered in a lime plaster; at a later date a green limewash was added to the external walls (Rai and Pandit 2000).

\section{Lime Mortar Composition}

From the scarce literary evidence relating to the composition of lime mortars used in India, it can be determined that they included: curd, jaggery, Bel pulp (from the fruit Aegel Marmalos), lentils and oil of Margosa (Singh et al. 1990). Experiments conducted by Singh et al. (1990) on these traditional mixes showed that Bel pulp increased the rate of carbonation of a mortar and that mortars containing oil were more resistant to weathering (Singh et al. 1990).

\section{The Use of Lime in Mesoamerica / South America}

Mesoamerican and South American history is dominated primarily by the large and complex civilisations of the Aztecs, the Mayans and the Incas. Prior to the emergence of these cultures, the continent was populated by many Neolithic tribes who dominated the Paleo-Indian period from 20,000 - 8000 BC (Alonso 2009). The first Mayan settlements were established c. $1800 \mathrm{BC}$ in the Soconusco region along the Pacific Coast (Alonso 2009); together with the Aztecs they dominated the area known as Mesoamerica. The Aztec empire consisted of several central Mexican ethnic groups who shared the Nahuatl language (Berdan 2004). They emerged in the $12^{\text {th }}$ 
century, with their capital being situated at Tenochitlan in the Valley of Mexico (Berdan 2004).

Mesoamerican history can be divided into five key time periods; these are as follows:

- Paleo-Indian $20,000-8000 \mathrm{BC}$ (the beginning of civilization in this region)

- Archaic $8000-2000 \mathrm{BC}$ (hunter gatherer societies moved towards a more sedentary lifestyle with the introduction of agriculture)

- Preclassic 2000BC $-250 \mathrm{AD}$ (the emergence of complex societies, kingship, writing and a period of general population growth)

- Classic 250-900/1000 AD (more complex political organisations, fluctuations in the power balance of societies)

- Post - Classic 900/1000 - 1519 AD (new centres developed along with trade, culminates in the Spanish conquest)

The Inca Civilization began as a tribe in the Cuzco area of South America c.1200 AD and remained in existence across Chile, Peru and Equador, until the arrival of the Spanish in the $16^{\text {th }}$ century (Dobyns and Dobyns 1976).

\section{The Incans}

\section{Early Construction Techniques}

Incan buildings were constructed from mud brick, fieldstones or worked blocks set as tightly packed ashlar courses (Hyslop 1990). Structures were commonly rectangular in form, with no internal walls and a thatched roof; such buildings often formed Kancha's - rectangular enclosures of three or more buildings constructed around a 
central courtyard. The Kancha's were often grouped together to form settlement areas within the cities, as can be seen at Ollantaytambo (figure 4), situated along the Urubamba River, Peru (Hyslop 1990).

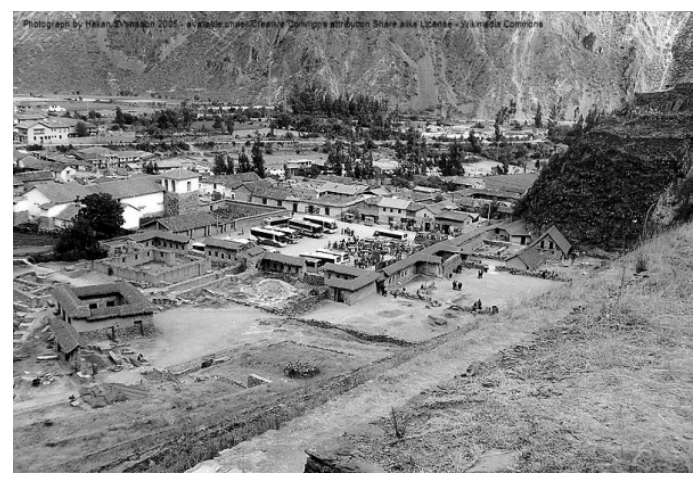

Fig.ure .4. The main square in Ollantaytambo, Peru (Håkan Svensson 2005 - made available under the Creative Commons Attribution Share Alike License - Wikimedia Commons).

Walls were generally constructed of porphyry or granite and were laid in thick but low structures (Prescott 2000). There are four classifications of Incan wall construction; these are as follows;

Encased Coursed Masonry - consisting of unaligned stone blocks Sedimentary Coarsed Masonry - consisting of blocks aligned in horizontal rows Cellular Polygonal Masonry - consisting of small irregular blocks packed together Cyclopean Polygonal Masonry - consisting of large irregular blocks packed together (Hyslop 1990).

The First Use of Lime and its Implementation throughout Time

Due to a lack of records, the first use of lime within the Incan Empire cannot be accurately pinpointed, however much is recorded in regards to the well known site of Machu Picchu, located on a mountain ridge above the Urubamba Valley in Peru. The 
site was constructed during the height of the Incan empire in c.1450 and was abandoned c. 1550 during the Spanish conquest. The complex of Machu Picchu consists of 140 structures, ranging from simple dwellings to temples and sanctuaries, as well as over 100 flights of stairs, some of which are carved from single blocks of granite (Hyslop 1990). Most of the buildings on the site are constructed from ashlar masonry that is so tightly fitted together that a knife can not be inserted between the blocks. Other buildings have been constructed using blocks and mortar, however these are considered to be substandard as they are less earthquake proof than the ashlar masonry (Hyslop 1990). Incan architecture is highly respected due to the durability of the construction and its high static and dynamic steadiness which allows it to withstand undue movement. Occasionally gaps in walls were filled with a mix containing lime or a bituminous substance (Prescott 2000).

\section{Lime Mortar Composition}

Analysis of the mortar by the early $19^{\text {th }}$ century antiquarian, Alexander von Humbolt (Prescott 2000), suggests that it was formed from a mixture of lime, clay and pebbles.. The bituminous substance is also thought to have been mixed with lime (Prescott op.cit.). Studies into Incan mortars are not as common as that of the material produced by the Maya; although the primary reason for this may be due to their greater work with ashlar masonry and stone work rather than plaster work. 


\section{The Mayans}

Early Construction Techniques

The Mayan civilization ranges from the Preclassic period to the Post-Classic period.

The Mayan lowlands consisted of several independent polities located on the Yucatan carbonate platform, which remained the source of limestone for the lime plasters throughout the duration of occupation, even for settlements not located directly on the platform itself (Alonso 2009).

The First Use of Lime and its Implementation throughout Time

Some of the earliest uses of lime in the Mayan world are the plastered platforms at Cuello, Belize dating to $1100-600 \mathrm{BC}$. Another early site seen to use lime as a plaster is that of Nakbè, Guatemala, which was occupied between $900-600 \mathrm{BC}$; a site which, as seen in figure 5, survives only as a series of ruins (Alonso 2009). Lime was occasionally used as a bonding mortar between the stones of the many Mayan monuments as well as for a paving material, however its use as a plaster (as seen in figures 6 and 7) is more common and therefore most referenced within the sources. 


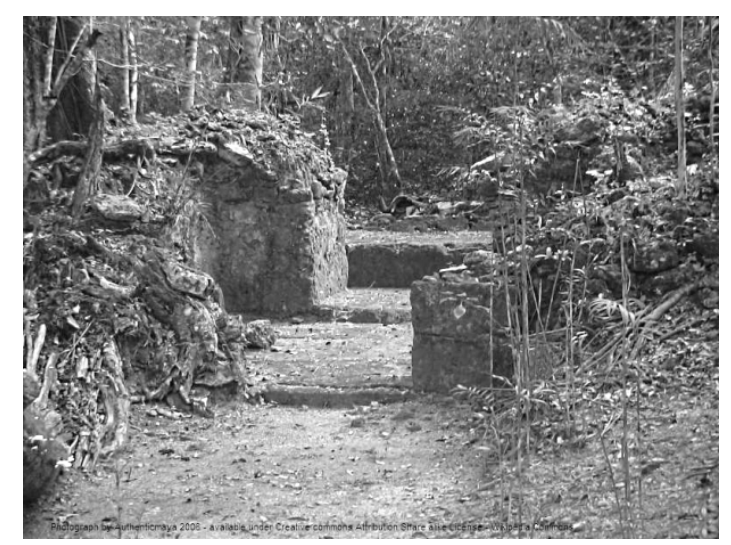

Fig.ure .5. The ruins of Nakbè, Guatemala (Authenticmaya 2006 - made available under the Creative Commons Attribution Share Alike License - Wikimedia Commons).

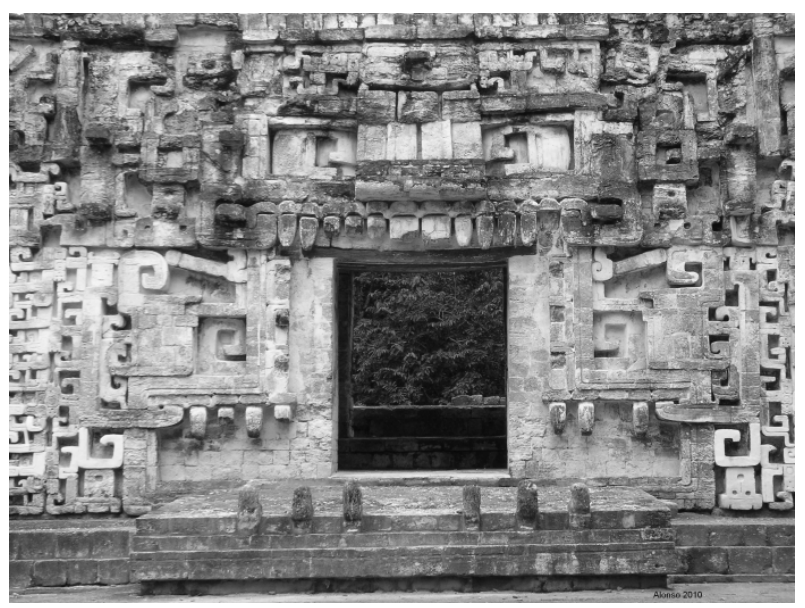

Figure ..6. A limestone façade plastered over with lime, from the site of Chicanná, in the Mexican state of Campeche (Alonso 2010).

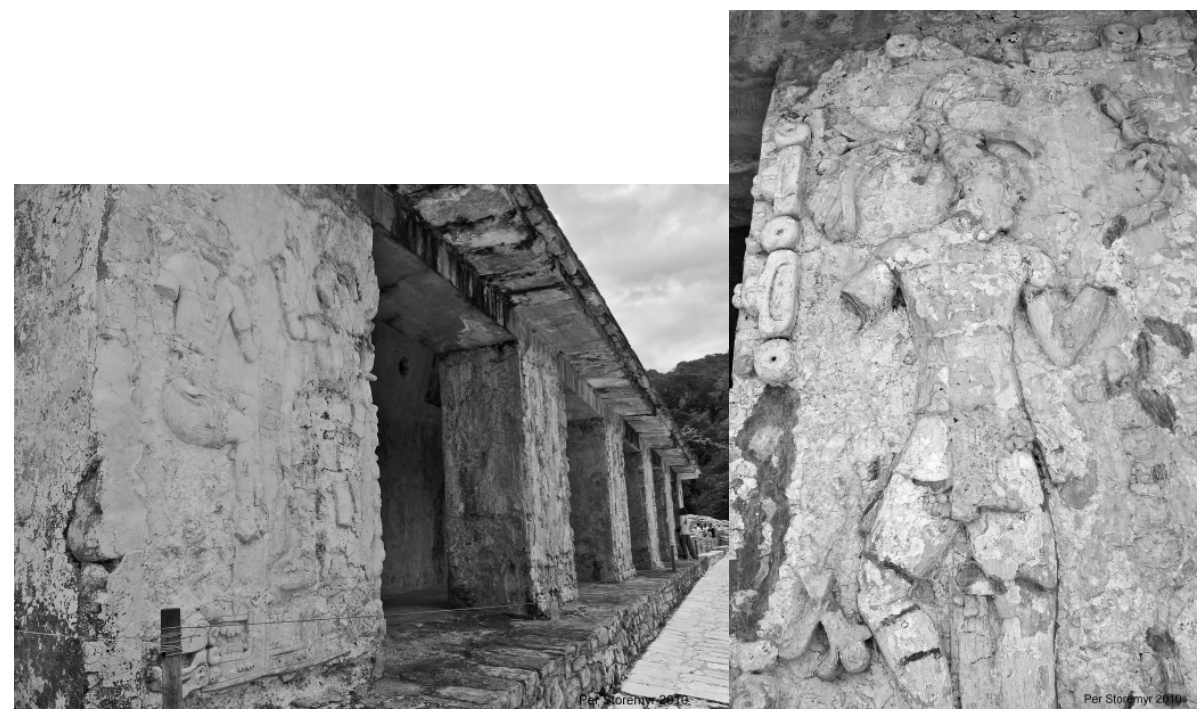

Fig.ure .7. A plaster stucco relief from the Palace complex at Palenque in the foothills of the Sierra de Chiapas, dating to 250 - 700 AD (Image - Per Storemyr 2010) 
Many large sites contain large monumental structures which used lime as a key building material. An example of one such building can be found at the city of Calakmul in Mexico which was occupied from the Middle Preclassic period to the Post classic period (Folan et al. 1995). Many of these Mayan monuments also used lime plaster as a substrate prior to painting and as a modelling material. Within structure II at Calakmul (figure 8), exists an older building which has been found to contain a frieze representing one of the oldest examples of lime plaster technology within the Mayan world. This frieze which dates to $400 \mathrm{BC}$ is 30 metres long by 3 metres high with a thickness of up to $12 \mathrm{~cm}$; figure depicts the temple in which it was found, however pictures of the frieze are yet to be released by the archaeologists for analysis (Alonso, pers comm.).

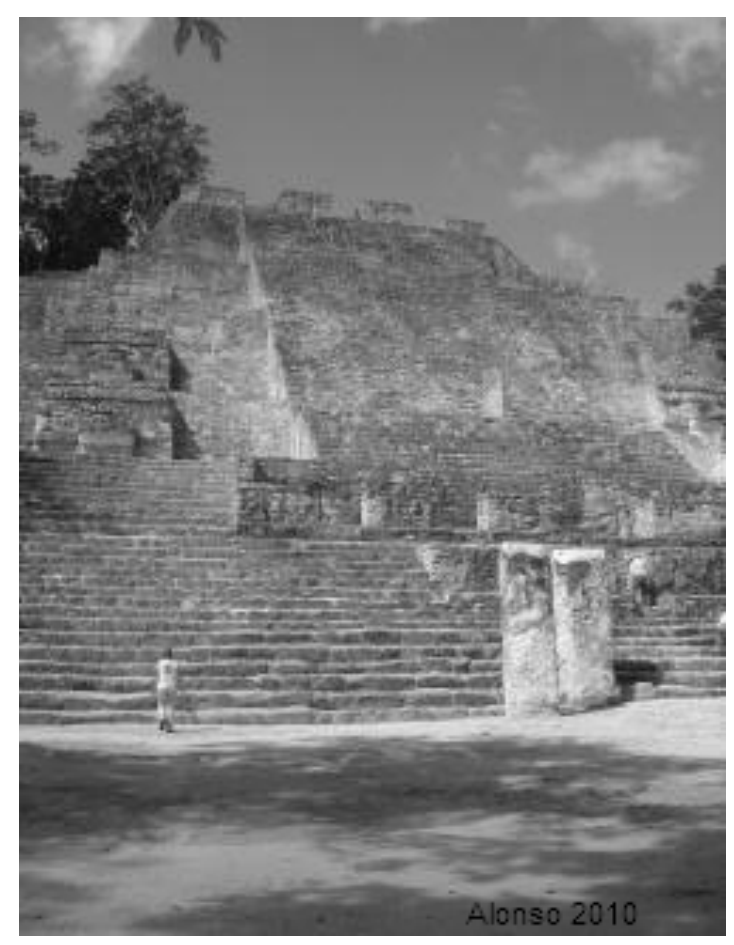

Figure ..8. Structure II, Calakmul, from the Mexican state of Campeche. This is one of the highest pyramids built within the Mayan area and contains within it an earlier structure which has been found to house a monumental frieze made from lime plaster (Alonso 2010). 
Little is written about the techniques used to make lime plaster in the primary sources of the period, so most of the detailed knowledge we have is gained from modern research. The references to lime within the Mayan writings are very brief.

Within House E of the Palenque city complex in the foothills of the Sierra de Chiapas $\left(5^{\text {th }}-8^{\text {th }}\right.$ Centuries AD), a glyph was found which could be translated as Sak Nuk (ul) Naah, meaning House of the White Skin (Alonso 2009). House E was the only house to be plastered in white plaster and not be painted red. Another glyph from vault 19 at Ek' Balam, Yucatan, Mexico, was translated as Sak Xok Naah, which means either Reading White House or White House of Respect, again relating to an area with white plastered walls (Alonso 2009). Later Mayan references to lime plaster can be found within the Popol Vuh, the sacred book of the Quiché Maya. The book, written in the $16^{\text {th }}$ Century, recorded the oral traditions of the Maya makes reference to the grinding of lime plaster and to the use of whitewash (Alonso 2009).

\section{Lime Mortar Composition}

Mayan lime shows a change in the knowledge of construction and building techniques over time. Villegas and Vázquez (1995) studied 103 lime plaster samples from houses E, B, C, A, D (in chronological order) and from the palace and several tombs. Through the analysis of these samples, they discovered that although the same source of lime was used over time, the sand became finer, which was thought to indicate an 
improvement in the grinding techniques of the aggregates used (Villegas and Vázquez 1995). They concluded that plaster reliefs within houses were added over different time periods and that there must have been a set of artisans dedicated to the production of such work (Villegas and Vázquez 1995). Alonso (2009), using samples from Palenque, Calakmul and Lamani (Northern Belize), has shown that through the Late Preclassic period (during which a great number of buildings were constructed) the thickness and quality of plasters increased. The Late Classic Period, then saw an increase in the binder: aggregate ratio of the plasters as well as an improvement in mixing techniques, a decrease in aggregate size and the addition of siliceous aggregates (Alonso 2009).

In general Mayan plasters contained calcareous aggregates and few charcoal fragments as a result of the use of the burning of firewood such as Chacah which leave no residue after burning (Alonso 2009).

Magaloni et al. (1995) have studied plaster samples from sixteen Mayan sites including Chichen Itza, Chelemi and Tancha, for the presence of amino acids in order to determine if biological additives were included in the mixes. They found that high amounts of Glutamic and Aspartic acids were present in the samples, although they could not clearly define the source of these amino acids. They did show that these acids reacted with the lime to restrict the growth of calcium carbonate crystals within the plaster, and that the resulting small crystalline texture made the plasters less vulnerable to heat and humidity (Magaloni et al. 1995).

\section{Lime Processing}


Although examples of applied lime plaster and mortar are common within the Mayan world, evidence of lime making and processing sites are scarce. The presence of cemented lumps of lime found within middens at many small scale Mayan sites are considered to be evidence of lime production (Mackinnon and May 1990). Mackinnon and May (1990) believe that they have identified a lime making station on the East side of Palancia Lagoon through the identification of a carbonate layer and characteristic pottery deposits. From a study of current lime burning practices in the region, they believe that the kiln would have consisted of layers of shells and wood, that would have been placed upon a possible platform of pottery platters (Mackinnon and May 1990).

Lime processing sites in general are hard to identify due to the natural occurrence of calcium carbonate; often infra-red spectrometry is required to extract what can be considered a tenuous distinction at best. This difficulty has meant that lime production and distribution in the Mayan world is not well understood (Mazullo et al. 1994) (Mackinnon and May 1990). Mazullo et al. (1994) found further evidence of lime working at the site of Santa Cruz, Ambergris Caye in Northern Belize. Within the occupational layers of this site, a relatively hard layer 1-3cm thick, of white to tan calcium carbonate intermingled with pottery sherds and charcoal, was found. The layer was deemed to be indicative of a recarbonated lime rather than a lime of a natural origin due to the presence of $\mathrm{CaO}$ and $\mathrm{MgO}$ (quicklime and magnesium quicklime) (Mazullo et al. 1994). This was also confirmed by the presence of polyhedral crystals with rounded faces, six sided crystals and crystals with shrinkage cracks, all of which are evidence of the processing of the lime (Mazullo et al. 1994). 


\section{The Aztecs}

\section{Early Construction Techniques}

Aztec architecture is referenced far less than that of Mayan architecture, even though it can be considered just as impressive. The Aztecs consisted of the Nahuatl speaking people of central Mexico who were at their height of power during the $14^{\text {th }}-16^{\text {th }}$ centuries. They derived from the Nahua who migrated into Mesoamerica from Northern Mexico in the $6^{\text {th }}$ Century AD (Berdan 2004).

The homes of the general Aztec populace were constructed from mud brick and thatch and consisted of a single room and a separate steam bath building (Wood 1992). Palaces were more elaborate, being two storey buildings constructed of stone. Temples are the most recognisable Aztec structure - these are seen as stepped buildings which were often highly modified by being built over several times (Wood 1992).

The First Use of Lime and its Implementation throughout Time

Many examples of Aztec structures remain throughout Mexico, one of these being the city of Malinalco, located south of the modern city of Toluca (Aguilar-Moreno 2007). The city, known by the Aztecs as Cuauhtinchan (eagle's nest), was taken c.1469 from the Matlatzinca and became famed for its temples and for its reputation as a fortress city (Aguilar-Moreno 2007). One of the temples, temple 3, was built to celebrate the 
funerals of fallen warriors (figure 9). It consists of a rock cut structure with a rectangular and a circular chamber inside. The walls of which are constructed from stone set within a soil and lime mortar (Aguilar-Moreno 2007).

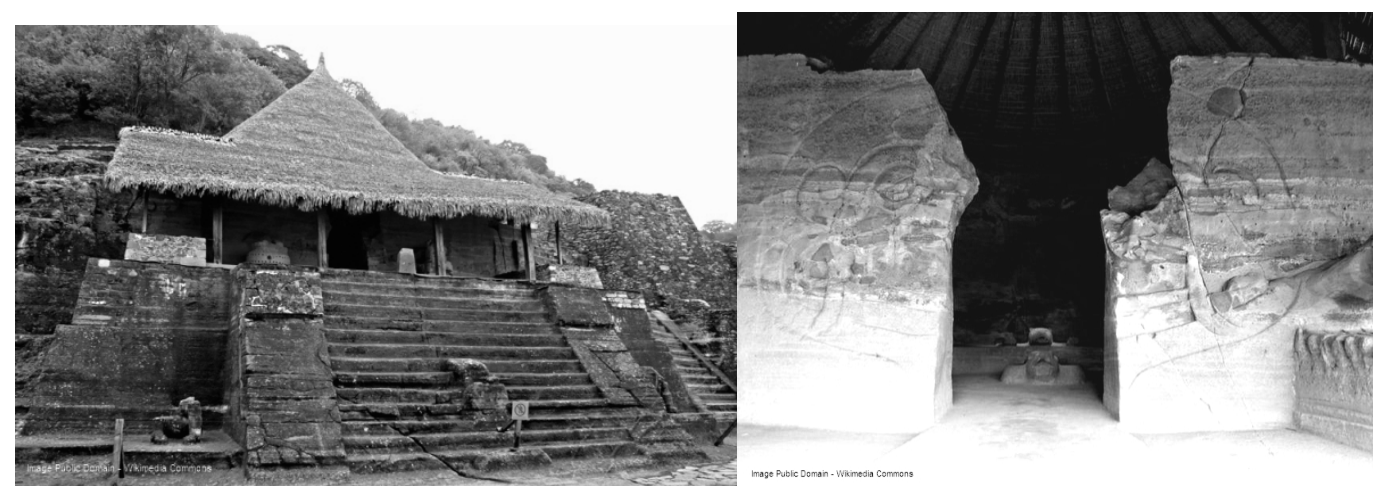

Figure ..9. The exterior of the Jaguar temple in Malinalco, located south of the modern city of Toluca. The image to the right is the interior of the temple (Image - Public Domain, Wikimedia Commons).

\section{Primary Sources}

As with the Mesoamerican tribes, little reference to construction is made within the primary literary sources of the era. However, there is a passing mention of lime in the Mendoza Codex, a document written after the Spanish conquest to document tributes. The codex was written in pictograms, one of which records the tribute of 4000 loads of lime to the province of Tepeac (Alonso 2009).

Studies of mortars within Mesoamerica and South America primarily focus on the Mayan civilisations and their use of the material. The reasons for this are purely conjecture, but this may be due to the accessibility of the sites studied, the preservation of the material, or the popularity of the subject. A disproportionate amount of data in regards to lime manufacture and use within the key settlements of this region has left a hiatus in the understanding of such a material and how its 
technology is transferred throughout the continent and between these civilisations, which needs to be addressed in future work.

\section{$\underline{\text { Africa }}$}

Most people know the history of Egyptian Africa and as mentioned earlier plaster was used within the pyramids as early as $1400 \mathrm{BC}$. However the use of lime mortar in the rest of Africa is rarely referenced, although many areas were largely influenced by Europeans, several areas did develop the use of lime independently.

\section{Early Construction Techniques}

The earliest known cities and states in Africa were situated along the middle Nile region known as Nubia; for example the settlement of Kerma, which was under occupation from c.8000 BC and became part of the Nubian dynasty c.2450 BC, consisted of many buildings built from mud brick (Connah 2001). Egypt was a separate civilization until the $8^{\text {th }}$ Century BC when the Nubians conquered Egypt and ruled as Pharaohs until the early $7^{\text {th }}$ Century BC. The Nubians were technologically sophisticated, often building in stone, fired brick and mud brick with mud mortar (Connah 2001).

Following the Nubians, North Africa was next dominated by the Phoenicians, before falling to the Greeks, the Romans, the Vandals, Byzantines, Arabs and eventually Napoleon (Manton 1988). The Hamites were the first dominant settlers to discover North Africa. Their occupation began c.4500 BC, and they gradually spread over 
Cyrenaica, Tripolitania, Numidia, Mauritania (Tunisia), Algeria and Morocco (Manton 1988).

The First Use of Lime and its Implementation throughout Time

By 1500 BC trade between Egypt and Crete was established by the Minoans. Shortly after, the Phoenicians began to take the coasts of the Levant and Israel under their control, before establishing small trading colonies in North Africa in the $9^{\text {th }}$ Century BC (Manton 1988). These became the sites of towns such as Utica and Djerba; however the most well known Phoenician settlement in Africa is that of Carthage, established in $814 \mathrm{BC}$ (figure 10); Carthage was the wealthiest city of the North African coast for 400 years. In 574 BC Carthage saw an increase in population as a result of the fall of the Phoenician capital Tyre to Nebuchadnezzar; this resulted in a spread of agricultural estates and a move away from the importance of coastal trade (Manton 1988). Many of these agricultural estates were dominated by large wealthy villas which were abundant in mosaics.

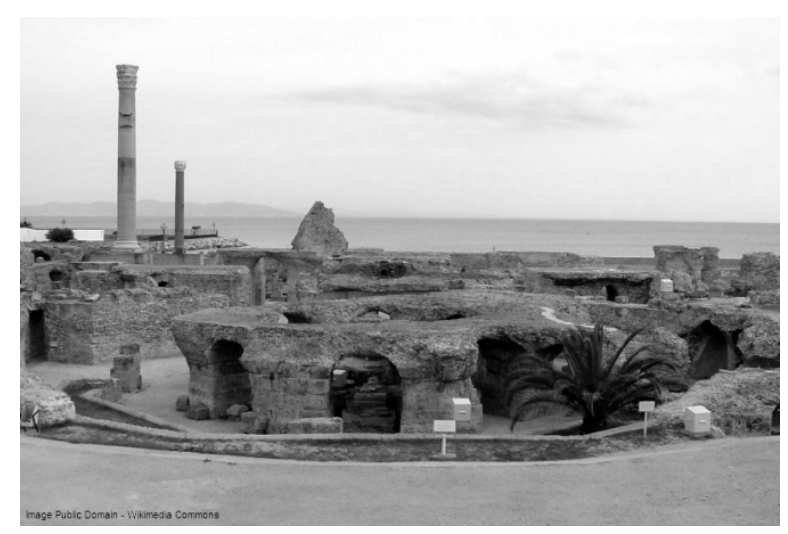

Fig.ure .10. The ruins of Carthage, North Africa (Image - Public Domain, Wikimedia Commons). 
It was known that the Phoenicians made use of lime mortar and plaster. They were the first to develop the cocciopesto mortars that became widespread throughout the Roman world. Cocciopesto mortars consist of lime, sand and brick fragments and were used either in moist environments (such as cistern linings) or as a foundation for flooring materials (Zendri et al. 2004). However, common Phoenician lime plasters from water cisterns have been analysed by the University of Michigan and have been found to contain $3-5 \%$ burnt organic material, a similar amount of crushed terracotta and $30-40 \%$ shell and sand in a 50\% lime matrix (Goodman 1998).

In 146 BC Carthage fell to Rome after many years of unrest between the two nations. The Romans incorporated Carthage into their Provincia Africa and declared Utica the capital. Towns were built upon old Punic (Carthaginian) sites and military towns such as Timigrad appeared (Manton 1988). These military towns were built by the Third Augustan Legion, and along with the new Roman towns, would have contained many common Roman structures such as temples, baths and amphitheatres. Here lime mortar would have been used widely for bedding stones, for plaster and for lining aqueducts.

One of the most famous examples of Roman aqueduct architecture survives in Carthage. The Aqueduct of Hadrian was built around $128 \mathrm{AD}$ and follows many of the rules set down in Vitruvius's De Architectura (Figueiredo et al. 2001). The aqueduct was built mainly from sandstone and limestone blocks bonded with a lime and sand mortar with a high mechanical strength. The aqueduct is not only valued for its state of preservation, but also because it shows a change in building styles which reflect the subsequent occupations of Carthage. When the Arabs took the city from the 
Romans in $698 \mathrm{AD}$, they too modified the aqueduct. They built the main rammed earth structure using lime and a reddish argillaceous earth formed within wooden moulds, emplaced from the bottom to the top. Once this had dried, they then coated the exterior with a thin mix of chalk or lime (Figueiredo et al. 2001).

Another major city in Africa was that of Cyrene, in the North East. Cyrene was founded by the Greeks in c.630 BC, around the time they were establishing the colonies that would later become the African cities of Ptolemais, Derna and Apollonia (Manton 1988). Cyrene was Hellenistic in form, containing an agora, gymnasium, temples, a basilica, a monumental gate and a theatre. In $528 \mathrm{BC}$ it became part of the Libyan Empire, however they did not alter the city; in $74 \mathrm{BC}$ the city fell to the Romans who continued to develop it (Manton 1988). Little needs to be said in this article about Cyrene as the architecture made heavy use of lime mortar and plaster in both the Roman and Greek buildings which dominated the city.

In $659 \mathrm{AD}$ the Arabs took Tunisia and built their holy city, Kairouan (still the fourth holiest city in Islam). The Arabs, as stated in Figueiredo et al. (2001), used lime for some of their buildings; for example the Great Mosque of Kairouan (figure 11), built in $670 \mathrm{AD}$, was constructed from sandstone bedded in lime mortar, which was repeatedly used for repair from its founding to present day (Manton 1988). 


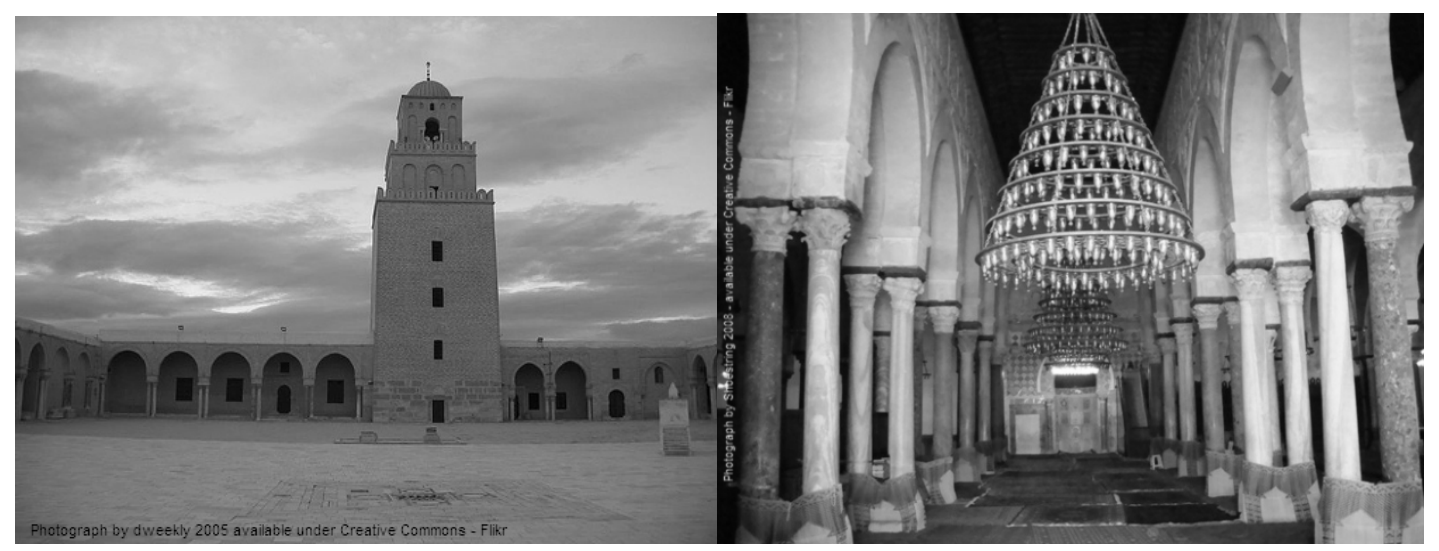

Figure ..11. The exterior and interior of the Great Mosque of Kairouan, built in 670 AD (Shoestring 2008 - made available under the Creative Commons Attribution Share Alike License -Flikr).

\section{East Africa}

Early Construction Techniques

Within East Africa traditional housing consisted of earth, pole and thatch structures that would have been replaced often. Earth, dung and ash are still used today as a construction material in many areas (Schilderman 1995a). Early Ethiopian history is dominated by the Aksumite period ( $4^{\text {th }}$ Century BC $-7^{\text {th }}$ Century AD) who used ashlar masonry and mud mortar in the construction of their palace complexes (Connah 2001). The Aksumites may have known of lime through their trade with the Romans and Egyptians; however they never used it in their structures.

The First Use of Lime and its Implementation throughout Time

The use of lime mortar in East Africa is dominantly found within Tanzanian coastal islands, such as Zanzibar and Pemba, and in the historic towns of Mombasa and 
Bagamoyu (Muhegi and Schilderman 1995). This appears to be due to the limitation of carbonate sources, which in these areas alone are abundant.

Within these East African coastal regions, buildings were predominantly mud and thatch with some coral stone and mud mortar, as seen at Kilwa which was occupied in $800 \mathrm{AD}$ (Connah 2001). The earliest uses of lime in these regions tend to be as a whitewash to protect the underlying mud and stone, however after the $12^{\text {th }}$ Century many coastal settlement saw an increase in the use of lime mortar and construction in stone in general. This often coincided with a change in economy from fishing to trade, resulting in an increase in wealth for such settlements (Connah 2001). For example; the town of Manda on an island in the Lamu Archipelago, was a flourishing town between the $9^{\text {th }}-19^{\text {th }}$ centuries. The earliest buildings were built from mud, wood, thatch and stone, with the occasional use of lime mortar to set the stone. From around the $10^{\text {th }}$ Century, mud mortar and stone construction dominated the town; in the $12^{\text {th }}$ Century this changed to lime mortar and stone, with a dramatic increase in the use of lime occurring in the $14^{\text {th }}$ Century (Connah 2001). It has been thought by some that this change to lime mortar and increase in stone construction may have been due to foreign influences, however a lack of evidence in favour of this belief has led to the conclusion that this process was an indigenous development (Connah 2001).

Small scale lime burning today would be a tradition that has continued almost unchanged from the past. The burning of the coral would have been done in heap kilns which if operated by a single person, could produce 1-2 heaps of lime a month, or if operated by a co-operative $15-20$ heaps a month (Muhegi and Schilderman 1995). 
Such kilns were $3.5-8 \mathrm{~m}$ in diameter and would have been made up of a pile of fuel (coconut poles and husks, wood and mangrove) $0.9-1.2 \mathrm{~m}$ high with a coral dome on top. Once the coral had been burnt, the outer layer of un-calcined material would have been removed and the rest would have been slaked (Muhegi and Schilderman 1995). Traditional kilns such as these are still used in Malawi; these are referred to as box kilns due to their shape (Ruskulis 1995). The box kiln has two trenches in the bottom into which wood is constantly fed. An arch of limestone is then placed over the trenches; alternating layers of limestone and fuel would complete the structure of the kiln. The limestone is burnt for 48 hours before the top of the kiln is sealed and left for eight days; the quicklime is then removed as and when it is needed (Ruskulis 1995). In Malawi, Tanzania and Kenya lime was used more as a decorative and protective render on walls rather than as a major construction material; even today it is more widely used in agriculture than construction (Ruskulis 1995).

Zanzibar is one of the oldest settlements in East Africa, however the use of lime as a binder only became common in the $18^{\text {th }}$ century (Schilderman 1995b). Within the low income areas it was used as a whitewash or as a wall infill between mud and pole walls, but within the town it was used in combination with ragstone (stone quarried in thin pieces) in the massive foundations of the historic houses. Most of the stone townhouses were limewashed and decorative stuccos made of lime plaster were common (Schilderman 1995b). 


\section{South Africa}

The later history of South Africa is dominated by the colonial activities of the Dutch and British. One of the oldest settlements attributed to the native South Africans is Great Zimbabwe, situated outside the town of Masvingu in the state which was named after the ruins, which was a massive drystone construction built by the Shone people in the $11^{\text {th }}$ Century (Connah 2001). Many smaller stone ruins exist (which are termed Zimbabwes'), but it is Great Zimbabwe that is the largest and finest in South Africa. The drystone walls are of a very sophisticated construction (figure 12) and are the common building method between the $11^{\text {th }}-14^{\text {th }}$ Centuries in this part of Africa (Connah 2001). The walls occasionally contained a very hard mud which was known as Daga (Connah 2001).

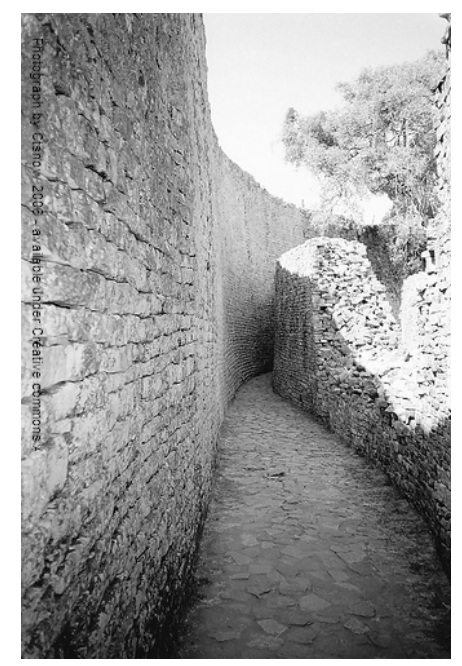

Figure .12.The well built drystone walls of Great Zimbabwe (Ctsnow 2006 - made available under the Creative Commons Attribution Share Alike License - Flikr).

The First Use of Lime and its Implementation throughout Time

Many of the indigenous sites of South Africa were of a simple construction; they consisted of huts built out of stone and mud in a beehive shape (Binckes 1998). 
It was not until the $16^{\text {th }}$ and $17^{\text {th }}$ Centuries, with the arrival of the colonists, that lime came to be commonly used in construction in South Africa. In 1652 the Dutch East India Company established a station on what is now Cape Town to resupply their ships. Gradually the site grew to become the centre of the South African colony, which was joined in the $19^{\text {th }}$ centuries by the British colonies of the Cape and Natal (Binckes 1998).

Cape Town's architecture reflected the Dutch fashions that occurred within the Netherlands; The Baroque buildings of the city consist of wings of rooms in a U, T or H plan that were plastered, limewashed and rooved with thatch (Binckes 1998). The Malay Quarter of Cape Town (figure 13) was home to the slaves and exiles brought in on the Dutch East India Corporation's ships. Here buildings were single or double storied and were built of soft brick with a stoep to the front; they were finished with plaster and whitewash (Binckes 1998). Many of the Victorian buildings of Cape Town were built with lime mortar and those that have stood the test of time have become popular dwellings for the wealthy. Several such buildings have been restored by private individuals or companies whilst others have been converted into museums and galleries (Binckes 1998).

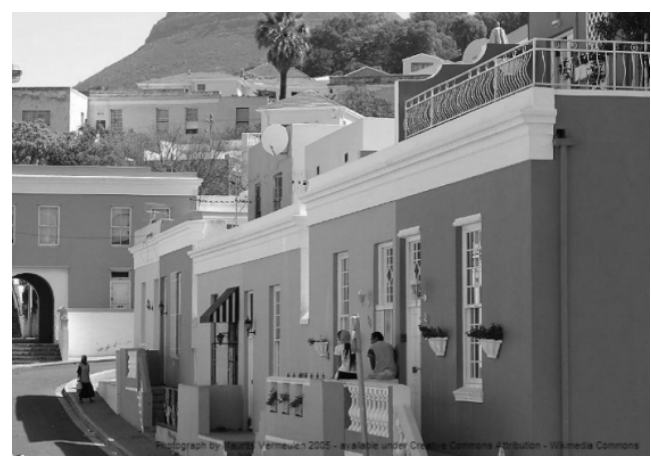

Figure ..13. Typical houses of the Bo-Kaap or Malay quarter of Cape Town, South Africa (Maurits Vermeulen 2005 - made available under the Creative Commons Attribution Share Alike License Flikr). 


\section{Concluding Remarks}

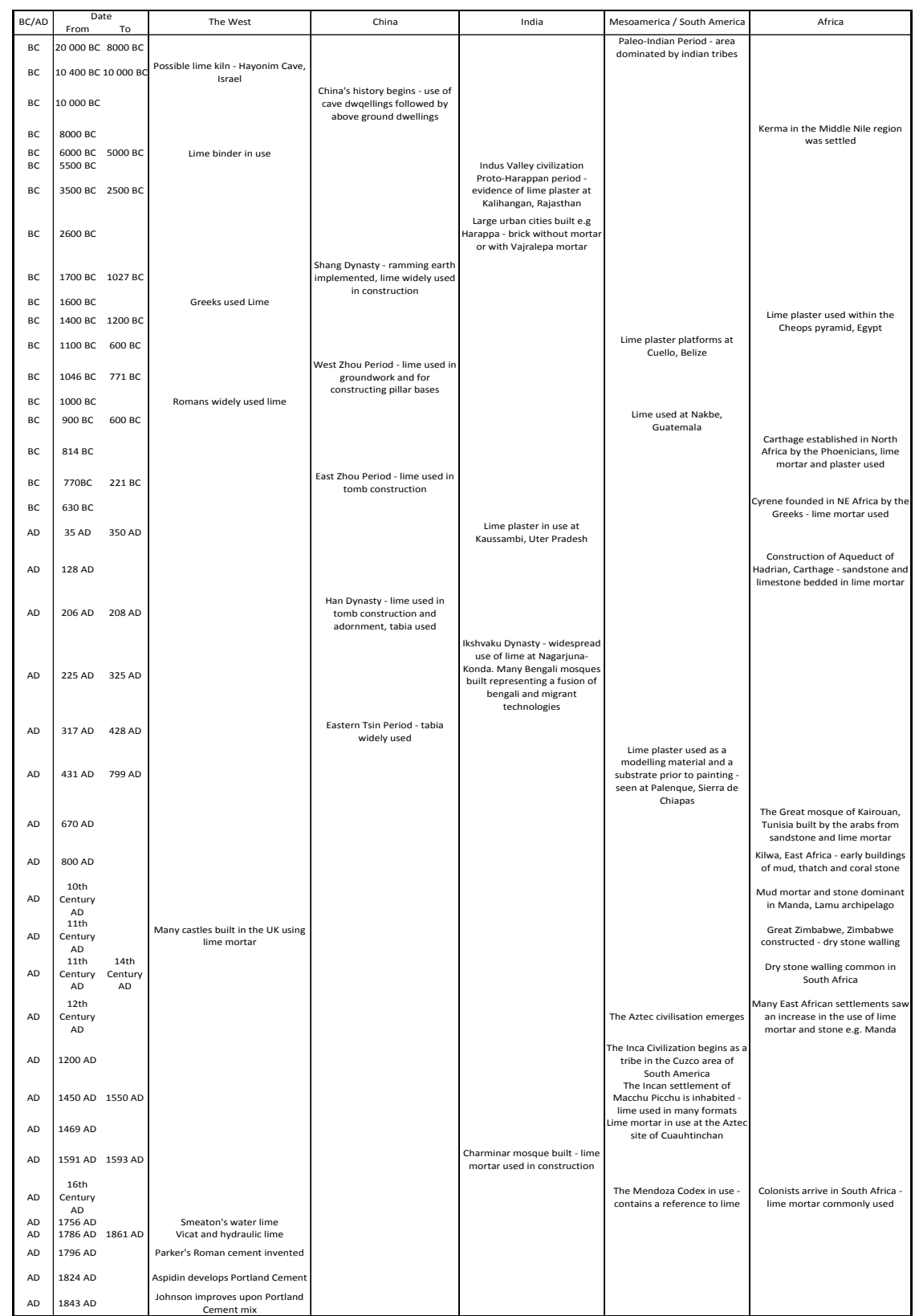

Table. 1. A comparative timeline of the key occurrences within the construction industries of China, India and the Surrounding Regions, Mesoamerica / South America, and Africa.

Of the regions discussed in this paper, the area with the earliest evidence of lime use is India, however here, as in most other civilisations it was first used in the form of a 
plaster. The only region where it was first used as a mortar rather than a plaster is China; this may be the result of a lack of information on the topic, or it may be that the Chinese used mediums other than plaster for their walls and artwork. It is known that some of the current cave dwellings in China do have plastered walls, so it is possible that the earlier dwellings may have used a similar substance for the same purpose (Golany 1992). Within the countries where lime was not used until a later period, Africa or Incan South America, stone was not always the primary construction material, or if it was, it was used without a form of mortar.

All the areas mentioned tend to favour the use of lime mortars that include organic additives. Studies on such mortars from China, India and Mayan limes, have all shown the benefits of such organic additives and that they were very varied in nature. Whilst little is known about organic additives to Roman mortars, British mortars were said to contain additives such as beer, wine and blood (Neve 1726). Considering that most of these additives are considered as strength and property enhancers for mortars, there is very little use of them in modern reconstructive mortars.

Normally construction in stone is seen as a symbol of wealth or political development; but the use of lime cannot be directly related to this assumption because from the onset it was used by the ordinary people of a civilisation for their own purposes, rather than for the elite; this is evidenced by its use as a plaster for the floors or walls of simple dwellings. The use of lime as a mortar however, may be more closely related to a representation of the transformation of a society into a more developed organisation or a symbol of elitism. This is illustrated by the East African settlements that showed a progressive development from primarily wooden structures to those 
constructed from stone and lime mortar, which was a reflection of an increase in wealth of their society. Such a model does not apply in countries and societies where dry stone walling is the dominant form of construction.

European societies have a clearer evolution of the use of lime mortar than the countries that have been discussed in this article. South America and Mesoamerica have a steady history of the use of lime whilst that of Africa is patchy in most places except the East. India and China show a small development from the use of plaster to mortar, but again their history of its use is quite continuous, but when compared to the wealth of information regarding the use of lime in Europe, they are still lacking. Whether this is a result of a lack of literary and physical evidence or study of the materials in these countries, it is unclear. What is known is that just because a country favoured the use of stone, does not mean that it was bonded with lime mortar and, as seen in China and India, the introduction of constructional elements such as brick and tile did not alter the use of lime, or at least not in a way that is evident. Sources relating to South America and Mesoamerica are often primarily related to a discussion of lime mortar due to the archaeological and historical importance of the material; however the sources that detail the history of building materials in general are often architectural in nature and contain only brief or no information in regards to the mortar used. Africa as a continent suffers from this problem greatly, as does China, although there may be some resources available that address this problem, but are inaccessible due to language barriers.

Today lime mortar is primarily used as a repair mortar for historic buildings. Most of the limestone quarries in existence produce stone only for aggregate use. In rural areas 
and countries lime is still used in construction on a small scale, and the same can be said for certain regions within the more urbanised countries. The uses of lime and its durability have been proven by centuries of use and it is a shame not to develop this ancient technology that has shown it can withstand earthquakes, floods and environmental changes.

Many of the civilisations mentioned in this article are some of the oldest in the world. Each appears to have developed the use of lime mortar independently prior to a dispersion of technology through trade and conquest. The individual development of such a technology would result in the segregation of a group of people within each society, who were skilled in the area of lime technology alone. Today, in many countries this link to the past has been broken by subsequent wars and technological developments; however we should never stop learning about the development of lime and its qualities as not only has it stood the test of time, but it has provided us with modern concrete, without which the modern architectural revolution would never have progressed as far as it has.

It is hoped that this article has bridged the gap between the knowledge of many relating to the known and unknown aspects of the history of mortar. It is by no means comprehensive as each continent has a widespread use of lime mortar; the history of which would span many pages if thoroughly studied. In the future it would be beneficial to see a greater comparison between mortars sourced from across the world and for a greater contrast to be made between cultural milestones and constructional development in order to enable a fuller understanding of a material which is essential to the history of architecture worldwide; as Kranzberg's $5^{\text {th }}$ law states; 
"All history is relevant, but the history of technology is the most relevant."

(Kranzberg 1986)

NB: All images have been reproduced with the permission of the authors or exist within the public domain with the exception of those that fall under the Creative Commons Attribution Share Alike License as stated - details of which are available at http://creativecommons.org/licenses/by-sa/2.5/

\section{References}

Aguilar-Moreno, M. (2007), Handbook of Life in the Aztec World (2nd Illustrated edn.: Oxford University Press USA) 464.

Alchin, L.K. (2005), 'Castles - Medieval Castles'.

Ali, S.A. (2001), 'The World's First Lime Mortar Building', The Times of India, 3/09/01.

Alonso, M.I.V. (2009), 'Lowland Maya Lime Plaster Technology: A Diachronic Approach', (University College London (UCL)).

--- (2010), Pers. Comm. E-mail to Dorn Carran 24/05/2010

Baronio, G., Binda, L., and Lombardini, N. (1996), 'The Role of Brick Pebbles and Dust in Conglomerates Based on Hydrated Lime and Crushed Bricks', in G. Baronio and L. Binda (eds.), Conv. 7NAMC (Notre Dame: Politechnico di Milano, Structural Engineering Department).

Berdan, F.F. (2004), The Aztecs of Central Mexico: An Imperial Society. (Belmont, California: Thomson - Wordsworth).

Binckes, G. (1998), 'Architectural Conservation in South Africa: The Cape Town Heritage Trust and its' Proposal for a National Trust', Architectural Conservation, 1, p. 68 - 81 .

Blezard, R.G. (1998), 'The History of Calcareous Cements', in P.C. Hewlett (ed.), Lea's Chemistry of Cement and Concrete (4th edn.: Arnold Publishers), p.1 23.

Boynton, R.S. (1980), Chemistry and Technology of Lime and Limestone (Second edn.; New York, Chichester, Brisbane, Toronto: Wiley Interscience, John Wiley and Sons Inc.) 578.

Connah, G. (2001), African civilizations: An Archaeological Perspective (Second edn.; Cambringe, UK: Cambridge University Press) pp. 340.

Degryse, P, Elsen, J, and Waelkens, M (2002), 'Study of Ancient Mortars from Sagalassos (Turkey) in View of their Conservation', Cement and Concrete Reserach, 32, 1457-63.

Dobyns, H.F. and Dobyns, P.L. (1976), Peru: A Cultural History (New York: Oxford University Press).

Elsen, J (2006), 'Microscopy of Historic Mortars -A Review', Cement and Concrete Reserach, 36, 1416-24.

Figueiredo, M.O., Veiga, J.P., and Silva, T.P. (2001), 'Materials and Reconstruction Techniques at the Aqueduct of Carthage since the Roman Period', in P.B. Lourenço and P. Roca (eds.), Historical Constructions, p. 391 - 400.

Folan, W.J., et al. (1995), 'Calakmul: New Data from an Ancient Maya Capital in Campeche, Mexico', Latin american Antiquity, 6 (4), p. 310 - 34.

Ghosh, A. (1990), An Encyclopaedia of Indian Archaeology (Illustrated edn.: BRILL) 413. 
Golany, G.S. (1992), Chinese Earth-Sheltered Dwellings - Indigenous Lessons for Modern Urban Design (University of Hawaii Press).

Goodman, M.M. (1998), 'The Effects of Wood Ash on the Structural Properties of Lime Plaster', (Masters Thesis, University of Pennsylvania).

Goren, Y and Goring-Morris, A.N. (2008), 'Early Pyrotechnology in the Near East: Experimental Lime Plaster Production at the Pre-Pottery Neolithic B site of Kfar Hattoresh, Israel', Geoarchaeology: An International Journal, 23 (6), 779-98.

Gourdin, W.H. and Kingary, W.D. (1975), 'The Beginnings of Pyrotechnology: Neolithic and Egyptian Lime Plaster', Journal of Field Archaeology, 2, p. 133 $-50$.

Grattan, F.J.H. (2008), 'An Introduction to Samoan Custom', (Victoria University of Wellington).

Hasan, P. (2007), Sultans and Mosques: The Early Muslim Architecture of Bangladesh. (Illustrated edn.: I.B.Tauris) 241.

Hughes, J.J. and Válek, J. (2003), Mortars in Historic Buildings: A Review of the Conservation, Technical and Science Literature (Historic Scotland: Technical Conservation, Research and Education Division) 80.

Hyslop, J. (1990), Inka Settlement Planning (Austin, Texas: University of Texas Press).

IGNCA (2009), 'Excavations - Important - Rajasthan', (Indira Gandhi National Center for the Arts).

Joseph, F. (2006), The Lost Civilization of Lemuria: The Rise and fall of the Worlds Oldest Culture (Bear and Company) pp. 360.

Karkanas, P (2007), 'Identification of Lime Plaster in Prehistory using Petrographic Methods: A Review and Reconsideration of the Data on the basis of Experimental and Case studies', Geoarchaeology: An International Journal, 22 (7), 775-96.

Kingary, W.D., Vandiver, P.B., and Prickett, M. (1988), 'The Beginnings of Pyrotechnology, Part II: Production and Use of Lime and Gypsum Plaster in the Pre-Pottery Neolithic Near East', Field Archaeology, 15 (2), p. 219 - 44.

Kranzberg, M. (1986), 'Technology and History: Kranzberg's Laws', Technology and Culture, 27 (3), pp. 544-60.

Kuban, D. (1974), Muslim Religious Architecture: (Netherlands: E.J.Brill).

Lal, B.B. (1997), The Earliest Civilisation of South Asia (Rise, Maturity and Decline) (Aryan Books International) 308.

Mackinnon, J.J. and May, E.M. (1990), 'Small-Scale Maya Lime Making in Belize', Ancient Mesoamerica, 1 (2), p. 197 - 203.

Magaloni, D., et al. (1995), 'Studies on the Mayan Mortars Technique', Materials Issues in Art and Archaeology - IV Symposium (352; Cancun, Mexico), p. 483 $-89$.

Manton, E.L. (1988), Roman North Africa (London: Seaby) pp. 144.

Mazar, A (1992), Archaeology of the Land of the Bible: 10,000-586 BCE (New York: Doubleday).

Mazullo, S.J., Teal, C.S., and Graham, E. (1994), 'Mineralogic and Crystallographic Evidence of Lime Processing, Santa Cruz Maya Site (Classic to Postclassic), Ambergis Caye, Belize', Journal of Archaeological Science, 21, p. 785 - 95.

Mercier, N., et al. (2007), 'Hayonim Cave: A TL-Based Chronology for this Levantine Mousterian Sequence', Journal of Archaeological Science, 34 (7), 1064-77. 
Muhegi, B. and Schilderman, T. (1995), 'Tazmania', in E. Agevi, O. Ruskulis, and T. Schilderman (eds.), Lime and Alternative Binders in East africa (Intermediate technology Publications in Association with the Overseas Development Administration), p. 3 - 30.

Neve, R. (1726), Neve's The City and Country Purchaser and Builder's Dictionary (Great Britain: David and Charles Reprints) pp. 285.

Pheng, L.S. (2001), 'Construction of Dwellings and Structures in Ancient China', Structural Survey, 19 (5), 262-74.

--- (2007), 'Managing Building Projects in Ancient China', Journal of Management History, 13 (2), 192 - 210.

Prakash, S. and Rawat, N.S. (1961), 'Chemical Study of Ancient Plasters found at Kausambi', Viynana Parishad Anusandhan Patrika, 4, p. 23 - 30.

Prescott, W.H. (2000), History of the Conquest of Mexico and History of the Conquest of Peru (Cooper Square Press).

Rai, G.S. and Pandit, M (2009), 'Krishan Temple: Project Profile', $<$ http://cms.unescobkk.org/index.php?id=2133>, accessed 12/02/09.

Roberts, J (1994), History of the World (Penguin).

Robertson, T., Simpson, J.B., and Anderson, J.G.C. (1976), The Limestones of Scotland (XXXV; Edinburgh: HMSO - Her Majesty's Stationary Office) 221.

Ruskulis, O. (1995), 'The Lime Industry in Malawi', in E. Agevi, O. Ruskulis, and T. Schilderman (eds.), Lime and Alternative Binders in East Africa (Intermediate Technology Publications in Association with the Overseas Development Administration), p. $104-07$.

Schele, L. (1986), 'Architectural Development and Political History at Palenque', in E.P. Benson (ed.), City-States of the Maya: Art and Architecture (Denver: Rocky Mountain Institute for Pre-Columbian Studies), p. 110-38.

Schilderman, T. (1995a), 'The Use of Binders in Low Income Housing', in E. Agevi, O. Ruskulis, and T. Schilderman (eds.), Lime and Alternative Binders in East Africa (Intermediate Technology Publications in Association with the Overseas Development Administration), p. 126 -27.

--- (1995b), 'Zanzibar', in E. Agevi, O. Ruskulis, and T. Schilderman (eds.), Lime and Alternative Binders in East Africa (Intermediate Technology Publications in Association with the Overseas Development Administration), p. 161 -62.

Sengupta, R. (2005), 'Influence of Certain Harappan Architectural Features on Some Texts of Eraly Historic Period'.

Seshan, K.S.S. (2009), 'Qutb Shahi Style (Mainly in and around Hyderabad City)', $<$ http://www.aponline.gov.in/Quick\%20links/HISTCULT/architecture qut.html $>$, accessed 12/02/09.

Sickels, L.B. (1987), 'Mortars in Old Buildings: an Historical and Practical Treatise', (University of Edinburgh).

Singh, M. (1993), 'Analysis and Characterization of Charminar Lime Plaster', Current Science, 64 (10), p. 760 - 64.

Singh, M., Jain, K., and Singh, T. (1990), 'Some Studies on the Suitability of Lime Mortars based on Ancient Indian Formulations for Restoration Purposes', Superfici Dell'Architettura: Le Finiture, Atti del Convegno di Studi (Bressanone, Italy), p. 151 - 58.

Smith, V.A. (1999), History of India: From 600 B.C. to the Muhammadan Conquest Including the Invasion of Alexander the Great (3rd edn.; New Delhi: Atlantic Publishers and Distributors). 
UPSA (2007), 'UP State Archives: Dating of Documents', (Uttar Pradesh State Archives).

Vicat, L. (1837), Mortars and cements (High Holborn, London: John Weale).

Villegas, M. and Vázquez, X. (1995), 'Relative Dating of the Stucco Relieves at Palenque, Chipas, Based on Variation in Material Preparation', Materials Research Society Symposium (352), p. 469 - 81.

Winfield, D (2006), 'Military, and Masonry Developments', in N Guy Wilson (ed.), Encyclopedia of Ancient Greece (Routledge), 800.

Wood, T. (1992), See Through History: The Aztecs (New York: Viking).

Yang, FuWei, et al. (2009), 'Traditional Mortar Represented by Sticky Rice Lime Mortar - One of the Great Inventions in Ancient China', Science in China Series E: Technological Sciences, 52 (6), p.1641 - 47.

Zendri, E., et al. (2004), 'Interaction Between Clay and Lime in "Cocciopesto" Mortars: A Study by ${ }^{29} \mathrm{Si}$ MAS Spectroscopy', Applied Clay Science, 25 (1-2), p. 1-7.

Zeng, YuYao, Zhang, BingJian, and Liang, XL. (2008), 'A Case Study and Mechanism Investigation of Typical Mortars used on Ancient Architecture in China', Thermochimica Acta, 473 (1-2), p. 1-6. 